\title{
Peningkatan Pengetahuan tentang Pemenuhan Gizi Balita di RW 04 Kelurahan Medono Kota Pekalongan
}

\author{
Ni'matul Ulya ${ }^{1}$, Pedvin Ratna Meikawati ${ }^{2}$ \\ Email: renex cubby@yahoo.co.id \\ Akademi Kebidanan Harapan Ibu Pekalongan \\ J1. Sriwijaya No 7 Pekalongan \\ Telp/Fax (0285) 4416108
}

\begin{abstract}
Abstrak
Anak balita adalah anak yang berusia dibawah 5 tahun. Konsumsi gizi yang baik dan cukup seringkali tidak bisa dipenuhi oleh seorang anak karena faktor eksternal maupun internal. Oleh karena itu sebagai orang tua kita juga harus berlaku demokratis untuk sekali-kali menghidangkan makanan yang memang menjadi kegemaran si anak. Intake gizi yang baik berperan penting didalam mencapai pertumbuhan badan yang optimal. Dan pertumbuhan badan yang optimal ini mencakup pula pertumbuhan otak yang sangat menentukan kecerdasan seseorang. Pemberian makanan pada anak dapat dipengaruhi oleh pengetahuan dan sikap ibu serta adanya dukungan keluarga dan lingkungan. Pengetahuan dan sikap ibu akan mempengaruhi asupan makanan yang ada di dalam keluarga terutama anak. Adapun tujuan dalam kegiatan pengabdian masyarakat ini adalah memberikan pengetahuan terkait gizi balita pada ibu-ibu yang mempunyai balita di Kelurahan Medono. Metode yang digunakan dengan edukasi melalui ceramah, tanya jawab dan diskusi. Hasil yang diperoleh pengetahuan ibu mengenai pemenuhan gizi balita meningkat. Sebelum dilakukan edukasi, ibu yang berpengetahuan baik sejumlah $50 \%$ dan setelah diberikan edukasi menjadi $80 \%$. Pada kegiatan tersebut juga dicapai komitmen yaitu ibu-ibu yang mempunyai bayi dan balita bersedia memberikan ASI Eksklusif dan bersedia memberikan MPASI yang kaya akan gizi
\end{abstract}

Kata Kunci : Gizi, Balita.

\begin{abstract}
Balita means children under 5 years old. The consumption of good and sufficient nutrition often cannot be fulfilled by a child due to external and internal factors. Therefore, as parents, we must also be democratic in order to serve food that is indeed the child's interest. Good nutrition intake plays an important role in achieving optimal body growth. And optimal body growth also includes brain growth that really determines one's intelligence. The food that consumed by the children can be influenced by the knowledge and attitudes of mothers and the support of family and the environment. The knowledge and attitude of the mother will affect food intake in the family, especially children. The purpose of this community service activity is to provide knowledge related to toddler nutrition to mothers who have toddlers in the Medono Village. The method used is education through lectures, questions and answers and discussions. The results obtained by mothers' knowledge regarding the fulfillment of toddler nutrition increased. Before education, $50 \%$ of knowledgeable mothers and $80 \%$ after being educated. In this activity a commitment was also reached, namely mothers who have babies and toddlers are willing to provide exclusive breastfeeding and are willing to provide MP-ASI which are rich in nutrition.
\end{abstract}

Keywords: Nutrition, Balita.

\section{Pendahuluan}

Anak usia dibawah lima tahun (balita) merupakan anak yang membutuhkan kecukupan gizi sebagai bekal untuk tumbuh dan berkembang optimal menuju masa depan yang sehat. Permasalahan gizi pada anak menjadi program prioritas dalam Program Indonesia Sehat dengan Pendekatan Keluarga $\left(\right.$ PISPK) ${ }^{(1)}$.

Proses pertumbuhan dan perkembangan anak yang berlangsung dengan cepat membawa 
konsekuensi meningkatnya kebutuhan nutrisi yang adekuat. Asupan nutrisi yang tidak adekuat dapat berdampak pada menurunnya daya tahan tubuh anak sehingga anak menjadi mudah terserang penyakit infeksi ${ }^{(2)}$.

Balita merupakan kelompok yang cukup rawan untuk mengalami gangguan gizi. Secara fisiologis keadaan gangguan gizi akan terjadi pada balita dan diperlukan antisipasi untuk mencegah gangguan gizi menjadi berlanjut dan menimbulkan berbagai komplikasi. Gangguan gizi balita mempunyai dampak yang cukup besar terhadap proses pertumbuhan balita. Bilabalita mengalami gangguan gizi maka akibat yang akan ditimbulkan antara lain:gizi buruk, gizi kurang, kwashiorkor, dan marasmus.

Pemenuhan nutrisi dan gizi yang optimal akan menghasilan pertumbuhan dan perkembangan yang signifikan pada seorang balita yang meliputi kematangan selimun, komposisi tubuh yang sesuai, perkembangan kognitif yang baik, serta kematangan organ metabolisme dan pencernaan. Jika kebutuhan nutrisi dan gizinya dengan baik, maka balita akan tumbuh menjadi dewasa yang sehat dan memiliki risiko minimal terhadap berbagai penyakit metabolik.

Selain pemenuhan nutrisi dan gizi yang baik, gaya hidup yang sehat turut membantu pembentukan tubuh yang sehat. Sekitar 20\% kondisi kesehatan secara keseluruhan ditentukan oleh gen bawaan manusia. Namun, 80\%-nya ditentukan oleh lingkungan yang mencakup pemenuhan nutrisi, gizi dan gaya hidup.

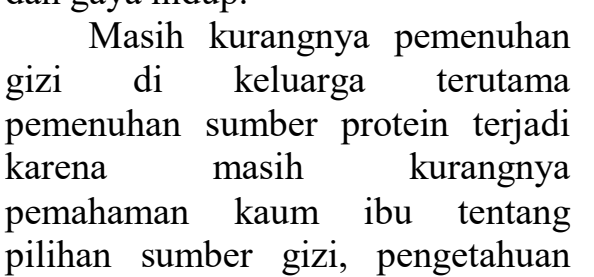

dan perilaku keluarga dalam memilih, mengolah, dan membagikan makanan ditingkat rumah tangga, ketersediaan air bersih dan fasilitas sanitasi dasar, serta ketersediaan dan aksesibilitas terhadap pelayanan kesehatan dan gizi masyarakat yang berkualitas ${ }^{(3)}$.

\section{Metode}

Kegiatan pengabdian masyarakat ini merupakan kerja sama Kelurahan Medono Kota Pekalongan dengan penyuluh yang berlatar belakang pendidikan bidan dan sebagai dosen di Akademi Kebidanan Harapan Ibu Pekalongan. Kegiatan pengabdian masyarakat dilaksanakan di rumah ketua RW 04 Kelurahan Medono serta dihadiri oleh 20 ibu yang mempunyai bayi/balita.

Penambahan informasi tentang gizi balita dilakukan dengan promosi kesehatan dari penyuluh kepada kelompok mitra serta motivasi untuk memberikan makanan pendamping ASI (MPASI) kaya akan gizi kepada anakanaknya. Penyuluh menyampaikan materi seputar kebutuhan zat gizi pada balita, pemantauan pertumbuhan balita, dan cara mengatasi kesulitan makan pada anak. Penyampaian materi diakhiri dengan sesi tanya jawab dan diskusi. Antusiasme peserta terlihat dari banyaknya pertanyaan dan hampir semua peserta memberikan pertanyaan seputar gizi balita.

\section{Hasil dan Pembahasan}

Kegiatan promosi kesehatan dengan tema pemenuhan gizi balita dilaksanakan di rumah RW 04 Kelurahan Medono Kota Pekalongan pada bulan Maret 2018. Kegiatan pengabdian masyarakat ini dinilai berhasil dengan indikator kehadiran peserta jumlah 20 orang dari 23 ibu yang mempunyai balita. Luaran kegiatan pengabdian masyarakat yang diselenggarakan 
berupa peningkatan pengetahuan tentang pemenuhan gizi pada balita.

Antusiasme peserta kegiatan pengabdian masyarakat bisa dinilai dari banyaknya pertanyaan yang diajukan serta adanya timbal balik dari peserta dengan menjawab pertanyaan yang diajukan oleh narasumber. Pada kegiatan tersebut juga dicapai komitmen yaitu ibu-ibu yang mempunyai bayi dan balita bersedia memberikan ASI Eksklusif dan bersedia memberikan MP-ASI yang kaya akan gizi. Komitmen yang diungkapkan peserta perlu diapresiasi dengan positif karena perubahan perilaku sangatlah tidak mudah, butuh waktu dan proses yang tidak singkat.

Tabel 1 Peningkatan Pengetahuan tentang Pemenuhan Gizi Balita

\begin{tabular}{|c|c|c|c|}
\hline & Pre & Post & Ket \\
\hline Baik & 10 & 16 & $\begin{array}{c}\text { Meningkat } \\
30 \%\end{array}$ \\
\hline Cukup & 6 & 3 & $\begin{array}{c}\text { Menurun } \\
15 \%\end{array}$ \\
\hline Kurang & 4 & 1 & $\begin{array}{c}\text { Menurun } \\
15 \%\end{array}$ \\
\hline Jumlah & 20 & 20 & \\
\hline
\end{tabular}

Tabel 1 di atas menunjukkan perubahan pengetahuan tentang pemenuhan gizi balita didapatkan peserta berpengetahuan baik sebelum diberikan informasi sebanyak $50 \%$ dan setelah diberikan pengetahuan menjadi $80 \%$.

Hal ini sesuai dengan teori Notoatmodjo (2012) dimana perilaku merupakan hasil daripada segala macam pengalaman serta interaksi manusia dengan lingkungannya yang terwujud dalam bentuk pengetahuan, sikap dan tindakan ${ }^{(4)}$. Hal ini sejalan dengan penelitian yang dilakukan Susilowati dan Sirait (2014) dimana seseorang berubah perilakunya setelah mendapat paparan pengetahuan yang dianggap baru dan sesuai dengan kondisi dirinya saat ini ${ }^{(5)}$.

Pengetahuan individu dapat diperoleh dari pengalaman langsung ataupun melalui pengalaman orang lain. Pengetahuan dapat ditingkatkan melalui penyuluhan baik secara individu maupun kelompok untuk meningkatkan pengetajuan kesehatan yang bertujuan untuk tercapainya perubahan perilaku individu, keluarga dan masyarakat dalam upaya mewujudkan derajat kesehatan yang optimal ${ }^{(4)}$.

Pembentukan perilaku individu membutuhkan berbagai metode yang tepat untuk sampai pada tahap perubahan perilaku seperti perilaku hidup sehat. Salah satu metode dalam pembentukan perilaku adalah dengan melalui pembiasaan. Pembiasaan merupakan metode perubahan perilaku individu dengan mengkondisikan situasi secara terus menerus hingga tercapai suatu kondisi yang diharapkan ${ }^{(6)}$.

Metode pembentukan perilaku selanjutnya adalah melalui pengertian. Pengertian erat kaitanyya dengan penegtahuan seseorang. Sebagai contoh, seorang ibu diberikan pengetahuan mengenai pemenuhan gizi yang cukup pada balitanya. Dikatakan gizi yang cukup adalah didlam menu MP-ASI (Makanan pendamping ASI) terdiri dari karbohidrat, protein, mineral dan zat vitamin yang dibutuhkan untuk pertumbuhan dan perkembangan otak balitanya.

Metode berikutnya adalah melalui contoh atau model. Model atau contoh sangat efektif untuk merubah perilaku individu. Dari model atau contoh yang dilihatnya, individu tersebut akan meniru dan akhirnya merubah perilaku mereka. Misalnya, model yang dilakukan oleh tenaga kesehatan saat posyandu memberikan MP ASI untuk balita di wilayahnya dengan menu yang seimbang dan gizi yang cukup, maka akan dicontoh oleh ibu-ibu 
yang mempunyai balita dalam memberikan MP ASI kepada balitanya.

\section{Kesimpulan}

Hasil yang diperoleh adalah pengetahuan ibu mengenai pemenuhan gizi balita meningkat. Sebelum dilakukan edukasi, ibu yang berpengetahuan baik sejumlah $50 \%$ dan setelah diberikan edukasi menjadi $80 \%$. Pada kegiatan tersebut juga dicapai komitmen yaitu ibu-ibu yang mempunyai bayi dan balita bersedia memberikan ASI Eksklusif dan bersedia memberikan MP-ASI yang kaya akan gizi

\section{Daftar Pustaka}

[1] Kementerian Republik Indonesi

Kesehatan Pedoman umum 2016.

\section{Indonesia} Sehat

Program pendekatan

Kementerian dengan keluarga.

Republik Indonesia: Jakarta.
[2] Hartono 2008. Tumbuh Kembang Anak dan Remaja, Jakarta: Sagung Seto.

[3] Supariasa,ID.N.,Bakri,B.,Fajar,I. 2001. Penilaian Status Gizi. Jakarta: EGC University Press.

[4] Notoatmojo. 2012). Promosi Kesehatan dan Perilaku Kesehatan. Jakarta: Rineka Cipta.

[5] Sulistiowati, E, Sirait, A.M. 2014. Pengetahuan Tentang Faktor Risiko. Penelitian Kesehatan, Vol 42 No 3 September 2014.

[6] Wawan, A dan Dewi. 2016. Teori \& Pengukuran Pengetahuan, Sikap dan Perilaku Manusia. Yogyakarta: Nuha Medika. 